\title{
Inflammatory parameters and blood lipid values across the different mood states in patients with bipolar disorder
}

\author{
Bipolar bozukluklu olgularda farklı atak dönemlerinde inflamasyon ve lipit \\ parametreleri
}

Okan Ekinci1 ${ }^{1}$ Aslı Erkan Ekinci1

${ }^{1}$ Assis. Prof.,Department of Psychiatry, Usak University, Usak, Turkey https://orcid.org/0000-0001-8059-9022-https://orcid.org/0000-0001-6331-9412

\begin{abstract}
SUMMARY
Objective: Recent studies indicate the role of impairment in immune regulation and inflammatory abnormality in Bipolar Disorder (BD). This study aims to compare these inflammatory markers and lipid values in different states of BD and healthy controls. Method: A retrospective observational study was carried out on a sample of patient admissions to the Department of Psychiatry of Usak University Hospital between November 1, 2017, and November 1, 2019, with a diagnosis of bipolar disorder in mania, depression, mixed episode, and remission. Results: We found that patients with BD in depressive and mixed states had higher levels of CRP, and patients with $B D$ in manic states had higher levels of MLR than other groups. There was no statistically significant difference at PLR and MPV values between groups. In terms of lipid levels, remitted bipolar patients had significantly higher Total Chol, TG, LDL, and VLDL levels than other patient groups and controls.Discussion: The present study suggests a close relationship between bipolar disorder, lipid metabolism and inflammation process. CRP may serve as a possible biomarker of mixed and depressive episodes of $B D$, while MLR may serve as a potential state biomarker of the manic episode. Our findings also claim that patients with $\mathrm{BD}$ experience impairment in lipid metabolism during remission and mixed episode and that this should be taken into account in the treatment management. Future prospective studies are needed to determine the exact role of inflammation and lipid metabolism on the different states of bipolar disorders.
\end{abstract}

Key Words: Bipolar disorder, inflammation, lipid, C reactive protein, monocyte/lymphocyte ratio

\begin{abstract}
ÖZET
Amaç: Güncel çalışmalar bipolar bozuklukta immün düzenlemede bozulma ve inflamatuvar anormalliğin rolüne işaret ederler. Bu çalışmanın amacı bipolar bozukluğun farklı evrelerinde ve sağlıklı bireylerde inflamasyon ve lipid değerlerini karşılaştırmaktır. Yöntem: Geriye dönük gözlemsel bu çalışma 1 Kasım 2017 ile 1 Kasım 2019 arasında Uşak Üniversite Hastanesi psikiyatri bölümüne başvuran mani, depresif, karma atakta veya remisyondaki bipolar bozukluklu olgularla gerçekleştirildi.Bulgular: Depresif ve karma ataktaki bipolar olguların daha yüksek CRP düzeylerine ve manik dönemdeki olguların daha yüksek MLR düzeylerine sahip olduklarını bulduk. PLR ve MPV değerleri açısından gruplar arasında farklılık yoktu. Lipid düzeylerinde ise remisyondaki bipolar olgular tüm gruplardan daha yüksek total kolesterol, LDL, Trigliserid ve VLDL değerlerine sahipti. Sonuç: Çalışmamız bipolar bozuklukla lipid metabolizması ve inflamasyon arasında bir ilişkiye işaret etmektedir. CRP bipolar depresif ve karma epizodların, MLR ise manik epizodun potansiyel bir biyolojik belirteci olabilir. Ayrıca bulgularımız remisyon ve karma dönemlerde lipid metabolizmasının bozulduğunu ve bu durumun tedavide gözönünde bulundurulması gerektiğini de öne sürmektedir. Bipolar bozukluğun farklı evrelerinde inflamasyon ve lipid metabolizmasının kesin rolünü saptamak için ileriye dönük çalışmalara ihtiyaç vardır.
\end{abstract}

Anahtar Sözcükler: Bipolar bozukluk, inflamasyon, lipit, $C$ reaktif protein, monosit lenfosit oranı 


\section{INTRODUCTION}

Bipolar disorder (BD) is a chronic mental disorder characterized by recurrent mood exacerbations with a frequency of around $1 \%$. To date, studies have not been able to reveal the exact pathophysiology of BD (1). However, current studies point to the importance of the immune system and inflammatory processes in the etiology of $\mathrm{BD}$. Furthermore, it is suggested that it may be possible to accept $\mathrm{BD}$ as a multisystemic inflammatory disease $(2,3)$.

The increase of pro-inflammatory cytokines during active episodes and remission and high comorbidity with autoimmune and inflammatory diseases are also signs that support the role of inflammation and immune modulation in BD (4-5, 6). Nowadays, there is increasing interest in other inflammation parameters such as $\mathrm{C}$ reactive protein (CRP) due to the short half-life, being an expensive and challenging evaluation of cytokines. C-reactive protein (CRP) is an acute-phase protein produced in response to an inflammatory stimulus and is mostly induced by the pro-inflammatory cytokines. CRP levels are unaffected by anemia, protein levels, red blood cell shape, or patient age or sex (7). It is known to be a reliable indicator of inflammation and used to evaluate low-grade inflammation in many somatic and mental disorders. It has been reported that CRP levels are higher in patients with BD than healthy individuals regardless of the episode, but it increases, especially during mania period (8).

In this area, the complete blood count parameters, as well as CRP, are utilized. Especially, neutrophil/lymphocyte ratio(NLR), platelet/lymphocyte ratio(PLR), mean platelet volume(MPV) and monocyte/lymphocyte ratio (MLR) are increasingly used to assess inflammatory status. These parameters are reported to be cheap, repeatable, and highly reliable to determine inflammation compared to cytokines and CRP. In particular, NLR and PLR have been studied as both predictive and prognostic factors in many systemic diseases $(9$, 10). Recently, there is growing evidence on the relationship between these variables and psychopathology in the field of psychiatry. Although the increase of inflammation in the manic period of BD has been well examined, the inflammatory condition in depressive and mixed episodes have rarely been investigated. In a limited number of studies, NLR, MLR, and PLR were evaluated for the predictive roles on the prognosis of the disease and their relationships with different states of BD (11, 12). MPV is a less well-treated marker of inflammation in $\mathrm{BD}$, and the findings regarding its association with the disease are contradictory in a limited number of studies. In these studies, the fact that inflammation has not been evaluated with a commonly used indicator such as CRP stands out as a significant deficiency. Besides, neglecting the patients with mixed state is another critical limitation in these studies $(11,13-14)$.

The inflammatory state in metabolic syndrome is often called low-grade chronic inflammation or metaflammation, meaning metabolically triggered inflammation (15). This chronic inflammation, due to oxidative stress and endoplasmic reticulum stress in adipocytes, leads to macrophage infiltration, abnormal cytokine production, and increased acute-phase reactants (16). Besides, activation of some receptors on adipose macrophages in response to lipids may lead to chronic inflammation in obesity $(17,18)$. On the other hand, lipid values and metabolic status have also been shown to have a close relationship with inflammation in patients with BD. Moreover, the current research has focused on these abnormalities in treatment processes $(19,20)$. However, to our knowledge, there has been only one study that simultaneously evaluated patients and healthy controls in terms of lipid and inflammation parameters (11). Therefore, we aimed to compare patients with different mood episodes and healthy controls in terms of inflammatory status and lipid values. We hypothesized that the inflammatory and lipid parameters would differ in various stages of $\mathrm{BD}$ and that there would also be some differences between the remission and the different mood states. We also hypothesized that there would be some differences in the inflammatory and lipid values between healthy individuals and those with $\mathrm{BD}$. 


\section{METHOD}

The study was conducted at the Usak University Faculty of Medicine Psychiatry Clinic. In total, 250 hospitalized patients, 142 outpatients, and 101 healthy controls from visitors to the hospital, with no major psychopathology, matched for age, sex, and education, were initially included in the study. All patients diagnosed with BD according to the Diagnostic and Statistical Manual of Mental Disorders, Fourth Edition(DSM-IV), diagnostic criteria were included in the study (21). The inclusion criteria were as follows: (1) older than 18 years of age and (2) diagnosed with BD according to DSM-IV diagnostic criteria. The exclusion criteria were as follows: (1) having an acute and chronic medical disease; (2) receiving anti-inflammatory, statin and immunosuppressive therapy; (3)obesity (BMI>30); and (4) dementia or cognitive deterioration according to DSM-IV criteria. All the patients underwent complete blood and urine testing, electrocardiography, and screening for acute infection based on a comprehensive physical examination, complete blood count, hepatic enzymes, and electrolytes. Only patients with normal ranges of the parameters mentioned above were included in the study. All CRP levels were below $11 \mathrm{mg} / \mathrm{dL}$, which reduced the chance that an acute physical illness was the cause of the inflammatory state (22). Besides, patients with a history of alcohol or drug dependence or traumatic head injury, any past or present major medical or neurological illness. The exclusion criteria and the age range for the controls were identical to those of the patient group. From the initial sample of 250 inpatients, 53 patients were excluded from the study because file data was missing. Twenty-one patients were excluded from the study due to substance and alcohol use or addiction in the registration examinations. Three patients were excluded due to mental retardation comorbidity and five patients due to co-diagnosis of cognitive impairment. 6 patients were excluded from the study due to comorbid chronic disease, $\mathrm{CRP}>11$, and the ongoing NSAI drug use. Thus, 162 consecutive inpatients were included in the final sample. From the initial sample of 142 outpatients who regularly followed by two authors (O.E, A.E); 8 were excluded from the study due to chronic disease and NSAI use, 16 due to lack of records and blood parameters, 20 were co-diagnosed with alcohol substance use disorder, five were excluded from the study due to the presence of cognitive impairment. Thus, 88 consecutive outpatients were included in the final sample.

The study was reviewed and approved by the ethical committee of Usak University Medical Faculty (Date: 15/01/2020; Decision number: 248-04). The subjects with BD were recruited from among patients hospitalized at the inpatient unit and outpatients who regularly followed by the authors of the study in Usak University Hospital. Sociodemographic and clinical variables were collected through a psychiatric interview and a detailed review of the digital patient charts and inpatient files. Data were retrieved from the electronic medical records of all patients between Nov 2017 and Nov 2019 at Usak University Hospital. The study utilized a retrospective, cross-sectional study of patients' records to obtain complete blood count, lipid, and CRP levels. All parameters were determined in the inpatient and outpatient psychiatry clinics as part of the routine laboratory tests conducted upon admission. At our clinics, fasting blood samples were collected between 7:00 and 8:00 AM. Weight and height were measured to calculate the body mass index (BMI). The following parameters were reviewed for all the subjects: highdensity lipoprotein cholesterol (HDL), low-density lipoprotein cholesterol (LDL), total cholesterol (TC), triglyceride (TG), C-reactive protein (CRP), and complete blood count. The NLR was calculated by dividing the absolute neutrophil count by the absolute lymphocyte count. The PLR was calculated by dividing the platelet count by the absolute lymphocyte count. For the serum lipid concentration, enzymatic methods were used, and serum levels of CRP were determined using sensitive regular immunoassays(ELISA) that allow the detection of a minimal concentration of $0.1 \mathrm{mg} / \mathrm{dL}$. All CRP levels were below $11 \mathrm{mg} / \mathrm{dL}$, which reduced the chance that an acute physical illness was the cause of the inflammatory state.

\section{Statistics}

We used SPSS for Windows 16.0 (Chicago, IL) for all the statistical analyses in this study. The variables were tested for homogeneity of variance 
using the Levene test and for the normality of distribution using the Kolmogorov-Smirnov test. Variables that did not follow normal distribution were analyzed using the Kruskal-Wallis test or the Mann-Whitney U test, otherwise Multivariate analysis of variance was used. Categorical variables (sex, marital status, place of residence, smoking status, drug treatment) were compared with the chi-square test. A multivariate analysis of covariance (MANCOVA) was used, with BMI, smoking, age, and sex as a covariate, to make the comparisons of complete blood count parameters, CRP and lipid values as the between-subject variables. MANCOVA analysis was performed with the group as the primary factor because multiple dependent variables were used. The significant main effects for groups were examined using Bonferroni corrections for each test to reduce type I errors. Bonferroni correction P values were determined based on number of dependent variables. According to this issue, $\mathrm{P}$ values less than 0.005 were considered statistically significant for the NLR, PLR, MLR, CRP, MPV, and lipid values.

\section{RESULTS}

A total of 250 patients ( 162 inpatients and 88 outpatients) and 101 healthy controls were included in the study. Of these patients, 78 were in mania $(31 \%), 51$ were in depression $(20 \%), 33$ were in mixed episodes (13\%), and 88 patients were in remission $(35 \%) .51 \%$ of the participants were female, and $49 \%$ were male. The mean age of the patient group was $41.27 \pm 11.29$, and the control group was $35.70 \pm 12.66$. There were no significant differences between the groups in terms of sex, duration of education, marital status. There were significant differences between the groups in terms of smoking status, place of residence, age, and BMI. In multiple comparisons, patients with manic episode were older than patients with other groups $(\mathrm{f}=6.62, \mathrm{p}<0.001)$. Patients with mixed and manic episode were found to have higher BMI than other groups $(\mathrm{f}=7.14, \mathrm{p}<0.001)$. Finally, the highest smoking rate $(72.7 \%)$ was found to be in patients with mixed episode $(\mathrm{X} 2=18.57, \mathrm{df}=4, \mathrm{p}=0.001)$ (Table 1).

NLR values were lower in patients with depressive state compared to patients with manic, mixed, euthymic state, and healthy individuals $(\mathrm{F}=4.22$, $\mathrm{p}=0.002)$. No significant differences were found between the groups in terms of PLR and MPV values ( $f=2.13 ; p=0.77 ; f=2.74, p=0.029)$. Patients with mixed and depressive states had higher CRP values than patients with manic state, while

Table 1. Socidemographic and clinical features of patients with bipolar disorder and healthy controls

\begin{tabular}{|c|c|c|c|c|c|c|c|c|}
\hline & & \multicolumn{4}{|c|}{ Bipolar Disorder } & \multirow{2}{*}{$\begin{array}{l}\text { Healthy controls } \\
\mathrm{N}=101\end{array}$} & \multirow[t]{2}{*}{ Statistic } & \multirow[t]{2}{*}{$\mathrm{p}$} \\
\hline & & $\begin{array}{l}\text { Mania } \\
\mathrm{N}=78\end{array}$ & $\begin{array}{l}\text { Depression } \\
\mathrm{N}=51\end{array}$ & $\begin{array}{l}\text { Mixed } \\
\mathrm{N}=33\end{array}$ & $\begin{array}{l}\text { Remitted } \\
\mathrm{N}=88\end{array}$ & & & \\
\hline \multirow[t]{4}{*}{ Gender } & Female & 45 & 27 & 15 & 40 & 46 & \multirow{4}{*}{$\begin{array}{l}F=3.75 \\
D f=4\end{array}$} & \multirow[t]{4}{*}{0.44} \\
\hline & & $57.7 \%$ & $52.9 \%$ & $45.5 \%$ & $45.5 \%$ & $45.5 \%$ & & \\
\hline & Male & 33 & 24 & 18 & 48 & 55 & & \\
\hline & & $42.3 \%$ & $47.1 \%$ & $54.5 \%$ & $54.5 \%$ & $54.5 \%$ & & \\
\hline \multirow[t]{4}{*}{ Place of residence } & Rural & 60 & 27 & 16 & 70 & 39 & \multirow{4}{*}{$\begin{array}{l}X^{2}=45.57 \\
D f=4\end{array}$} & \multirow[t]{4}{*}{$<0.001$} \\
\hline & & $76.9 \%$ & $52.9 \%$ & $48.5 \%$ & $79.5 \%$ & $38.6 \%$ & & \\
\hline & Urban & 18 & 24 & 17 & 18 & 62 & & \\
\hline & & $23.1 \%$ & $47.1 \%$ & $51.5 \%$ & $20.5 \%$ & $61.4 \%$ & & \\
\hline \multirow{4}{*}{$\begin{array}{l}\text { Cigarette } \\
\text { smoking }\end{array}$} & No & 27 & 21 & 9 & 52 & 51 & \multirow{4}{*}{$\begin{array}{l}X^{2}=18.57 \\
D f=4\end{array}$} & \multirow[t]{4}{*}{0.001} \\
\hline & & $34.6 \%$ & $41.2 \%$ & $27.3 \%$ & $61.9 \%$ & $50.5 \%$ & & \\
\hline & Yes & 51 & 30 & 24 & 32 & 50 & & \\
\hline & & $65.4 \%$ & $58.8 \%$ & $72.7 \%$ & $38.1 \%$ & $49.5 \%$ & & \\
\hline \multirow[t]{4}{*}{ Marital status } & Single & 44 & 25 & 13 & 42 & 40 & \multirow{4}{*}{$\begin{array}{l}F=2.78 \\
D f=4\end{array}$} & \multirow[t]{4}{*}{0.52} \\
\hline & & $\% 56.4$ & $50 \%$ & $39 \%$ & $48 \%$ & $40 \%$ & & \\
\hline & Married & 34 & 25 & 20 & 46 & 61 & & \\
\hline & & $\% 43.6$ & $50 \%$ & $61 \%$ & $52 \%$ & $60 \%$ & & \\
\hline \multirow{8}{*}{ Medication profile } & Lithium $($ Li $)$ alone & $9(11.5 \%)$ & $8(15.8 \%)$ & $3(9.1 \%)$ & $19(21.6 \%)$ & - & \multirow{7}{*}{$\begin{array}{l}X 2=15.27 \\
D f=4\end{array}$} & \multirow[t]{7}{*}{0,011} \\
\hline & Sodium valproate(Valp) alone & $11(14.1 \%$ & $4(7.8 \%)$ & $3(9.1 \%)$ & $15(17.0 \%)$ & - & & \\
\hline & Li+Valp & $20(25.7 \%)$ & $8(15.8 \%)$ & $4(12.1 \%)$ & $10(11.4 \%)$ & - & & \\
\hline & Li/Valp+ Antipsychotic(AP) & $24(30.8 \%)$ & $17(33.3 \%)$ & $14(42.4 \%)$ & $24(27.3 \%)$ & - & & \\
\hline & AP alone & $10(12.8 \%)$ & $1(1.8 \%)$ & $5(15.2 \%)$ & $10(11.4 \%)$ & - & & \\
\hline & Antidepressants + Li/Val/AP & $0(0 \%)$ & $11(21.7 \%)$ & $0(0 \%)$ & $3(3.4 \%)$ & - & & \\
\hline & Other & $4(5.1 \%)$ & $2(3.8 \%)$ & $4(12.1 \%)$ & $7(7.9 \%)$ & - & & \\
\hline & & Mean-SD & Mean-SD & Mean-SD & Mean-SD & Mean-SD & & \\
\hline \multicolumn{2}{|c|}{ Age } & $44.0-11.45$ & $38.7-12.02$ & $39.8-9.54$ & $42.59-12.16$ & $35.70-12.66$ & $\mathrm{~F}=6.62$ & $<0.001$ \\
\hline \multicolumn{2}{|c|}{ Education level (years) } & $8.91-2.24$ & $9.37-2.89$ & $9.39-2.98$ & $9.00-2.37$ & $9.22-2.84$ & $\mathrm{~F}=0.41$ & 0.801 \\
\hline \multicolumn{2}{|c|}{ The number of hospitalization } & $3.31-2.52$ & $3.18-2.48$ & $3.51-2.91$ & $2.03-1.81$ & --- & $\mathrm{F}=5.14$ & 0.021 \\
\hline \multicolumn{2}{|c|}{ Age at ilness onset } & $25.61-10.3$ & $24.9-8.21$ & $22.51-8.31$ & $24.71-7.32$ & --- & $\mathrm{F}=1.04$ & 0.564 \\
\hline \multicolumn{2}{|l|}{ Body Mass Index } & $28.26-4.64$ & $26.11-3.31$ & $29.39-5.88$ & $24.72-3.72$ & $24.39-3.69$ & $\mathrm{~F}=7.14$ & $<0.001$ \\
\hline
\end{tabular}


Table 2. Comparison of patients and controls in terms of lipid and inflammation parameters

\begin{tabular}{|c|c|c|c|c|c|c|c|c|}
\hline & \multicolumn{4}{|c|}{ Bipolar Disorder } & \multicolumn{4}{|l|}{ Healthy } \\
\hline & $\begin{array}{l}\text { Mania (M) } \\
\mathrm{N}=78\end{array}$ & $\begin{array}{l}\text { Depression(D) } \\
\mathrm{N}=51\end{array}$ & $\begin{array}{l}\text { Mixed(MX) } \\
\mathrm{N}=33\end{array}$ & $\begin{array}{l}\text { Remitted (R) } \\
\mathrm{N}=88\end{array}$ & $\begin{array}{l}\text { Controls (HC) } \\
\mathrm{N}=101\end{array}$ & $\begin{array}{l}\text { Statistic } \\
\text { Mancova }\end{array}$ & $\mathrm{p}$ & \multirow[t]{2}{*}{$\begin{array}{l}\text { Post-hoc } \\
\text { Comparisons }\end{array}$} \\
\hline $\begin{array}{l}\text { Inflammation } \\
\text { parameters }\end{array}$ & mean-SD & mean-SD & mean-SD & mean-SD & mean-SD & & & \\
\hline$M P V$ & $9.38-1.09$ & $9.32-1.03$ & $9.23-0.98$ & $9.23-0.98$ & $9.63-1.24$ & 2.745 & 0.029 & $\mathrm{HC}>\mathrm{D}, \mathrm{M}, \mathrm{MX}, \mathrm{R}$ \\
\hline$C R P$ & $2.23-2.15$ & $3.02-2.99$ & $2.20-2.46$ & $1.48-2.02$ & $1.57-2.12$ & 10.415 & $<0.001$ & $\mathrm{D}, \mathrm{MX}>\mathrm{M}>\mathrm{HC}, \mathrm{R}$ \\
\hline$P L R$ & 114.34-34.39 & $107.02-51.37$ & $101.89-21.82$ & $127.41-48.07$ & $121.15-80.80$ & 2.130 & 0.077 & N/A \\
\hline$M L R$ & $0.24-0.13$ & $0.19-0.06$ & $0.21-0.09$ & $0.22-0.05$ & $0.19-0.05$ & 9.268 & $<0.001$ & $\mathrm{M}>\mathrm{R}>\mathrm{MX}>\mathrm{D}, \mathrm{HC}$ \\
\hline$N L R$ & $1.81-0.93$ & $1.47-0.67$ & $1.81-0.97$ & $2.29-1.21$ & $2.12-1.08$ & 4.223 & 0.002 & $\mathrm{D}<\mathrm{R}, \mathrm{HC}, \mathrm{MX}, \mathrm{M}$ \\
\hline \multicolumn{9}{|l|}{$\begin{array}{l}\text { Lipid } \\
\text { parameters }\end{array}$} \\
\hline Trigliserid & $144.50-78.47$ & $121.53-72.55$ & $164.64-114.40$ & $166.27-86.58$ & $125.43-46.26$ & 7.573 & $<0.001$ & $\mathrm{R}, \mathrm{MX}>\mathrm{M}, \mathrm{D}>\mathrm{HC}$ \\
\hline Cholesterol & $185.38-42.03$ & $171.88-46.05$ & $171.27-36.56$ & $202.00-45.23$ & $175.00-30.85$ & 11.950 & $<0.001$ & $\mathrm{R}>\mathrm{M}, \mathrm{D}, \mathrm{MX}>\mathrm{HC}$ \\
\hline$H D L$ & $49.65-12.35$ & $48.51-9.03$ & $42.19-13.82$ & $47.74-12.13$ & $45.45-9.93$ & 2.957 & 0.020 & $\mathrm{M}, \mathrm{D}, \mathrm{R}>\mathrm{MX}, \mathrm{HC}$ \\
\hline$L D L$ & $107.63-31.67$ & $99.07-36.80$ & $96.15-28.89$ & $121.01-41.28$ & $104.46-24.38$ & 12.192 & $<0.001$ & $\mathrm{R}>\mathrm{M}, \mathrm{D}, \mathrm{MX}>\mathrm{HC}$ \\
\hline$V L D L$ & $28.87-15.70$ & $24.30-14.51$ & $32.92-22.88$ & $33.25-17.32$ & $25.08-9.25$ & 7.578 & $<0.001$ & R. MX>M.D.C \\
\hline
\end{tabular}

patients with manic state had higher CRP values than euthymic patients and healthy controls $(\mathrm{f}=10,42, \mathrm{p}<0.001)$. On the other hand, MLR values were significantly higher in patients with manic state than those with mixed, depressive and euthymic state, and controls, but there was no difference between patients with depression and healthy controls $(\mathrm{f}=9,27, \mathrm{p}<0.001)$ (Table 2).

Regarding lipid values, patients with mixed episodes and remitted patients had significantly higher triglycerides compared to all other groups $(\mathrm{f}=7.57, \mathrm{p}<0.001)$. Patients in remission had significantly higher LDL and total cholesterol values than those with manic, depressive, and mixed state. It was found that healthy controls had lower LDL and total cholesterol values than all patient groups. $(\mathrm{f}=12,19, \mathrm{p}<0.001$ and $\mathrm{f}=11,95, \mathrm{p}<0.001$, respectively) (Table 2).

\section{DISCUSSION}

Our study showed that CRP values were higher in patients with depressive and mixed episode than patients with mania and euthymic and healthy controls, while MLR values were significantly higher in patients with manic episode compared to patients with other groups and healthy controls. On the other hand, PLR and MPV values do not differ between patients and controls. Our findings support the association of low-grade inflammation with $\mathrm{BD}$ and suggest that CRP value may be a potential biomarker for mixed and depressive states, while MLR value may be a potential biomarker for manic state.
In our study, we found no difference in NLR values between patients with manic, mixed and euthymic state, and healthy individuals. Aykut et al. (2018) found no statistically significant difference in NLR between euthymic BD and control group, while Ivkovic et al. (2016) observed increased NLR in $\mathrm{BD}$ euthymic compared to healthy controls (23, 24). Also, it has been reported that patients with BD had higher NLR values than healthy controls, but there was no difference at these values between patients with different states (mania, depression, and euthymia) $(25,26)$. As previous studies did not evaluate patients for mixed episodes, it is difficult to compare their findings with our research. Another notable point is that factors such as BMI, smoking, and age, which are expected to affect the level of inflammation, were not controlled when comparing groups in the studies reported significantly higher NLR in patients with BD. Besides, when comparing closely related inflammation parameters in a multivariate model, a failure to perform statistical correction of significance values can also be considered as a methodological deficiency $(11,25,27)$. In conclusion, our study suggests that NLR values may not be a good indicator of inflammation in different states of BD, contrary to previous findings.

We also found no significant differences between patient and control groups in terms of MPV and PLR values. Both these parameters reflect platelet number and volume, which are considered to be one of the determinants of inflammation in the literature. Studies reported that PLR values were higher in patients with manic and euthymic states than healthy controls $(14,26)$. Recently, Binici et 
al. (2018) reported no significant difference at PLR values between patients with $\mathrm{BD}$ and healthy controls. This study shows the methodological similarity with our study. For example, the age and BMI as covariate variables were included in the multivariate model, and the level of significance was redetermined with Bonferroni correction in this study (28).

On the other hand, the findings regarding MPV is contradictory in the literature. MPV values were reported to bee higher in patients with BD than healthy controls (14), while some studies were found to be lower than healthy controls (13). It is important to note that the type of patients' episodes was ignored; the comparisons were not controlled for confounding variables such as smoking, age, and BMI in both studies. Therefore, well-designed prospective studies on a larger sample are needed to determine whether MPV and PLR are simple markers of inflammation in BD.

In our study, CRP values were found to be higher in patients with mania, depressive, and mixed states than those with the euthymic phase. While there were no differences between patients with depressive and mixed state, it was remarkable that the patients with these episodes had higher levels of CRP than those with the manic state. Although most studies found an increase in CRP concentration during manic state, the data regarding depressive, mixed, and euthymic states is less clear (29, 30). In a recent meta-analysis study, CRP levels were reported to be higher in patients with manic periods than healthy controls and patients with depressive and euthymic states (8). Furthermore, it has been suggested that increasing CRP levels during the depressive period can predict future manic episodes (31). In our study, higher CRP levels in manic and depressive states support previous findings in the literature. However, the result of higher CRP levels in patients with mixed state is a new addition to the research. Almost $40 \%$ of patients with $\mathrm{BD}$ experience mixed episodes, and this rate is likely to rise further, along with the DSM-5 criteria (32). Although patients experiencing mixed symptoms were reported to be different not only clinically but also etiologically from the other bipolar patients, the pathogenesis of mixed episodes could not be fully clarified (33). The role of inflammation in the pathogenesis of mixed symptoms or mood swings has not yet been investigated, and this area seems to be worth investigating, given the higher level of CRP in mixed states in our study.

Another important finding of the study is that MLR values were significantly higher in patients with manic state compared to patients with depressive and mixed state and healthy controls. This finding has been previously reported in a small number of studies $(11,34)$. MLR is a low-cost and relatively new predictor of white blood cell count. One study reported that increased expression of immune genes and overproduction of cytokinesassociated macrophages increased monocyte count in psychiatric patients (35). Pro-inflammatory cytokines released from activated monocytes can be an explanation of the relationship between mood and MLR (36). It is also reported that a large proportion of patients with BD have an inflammation gene expression related to mood swings. (37). This finding, supported by a limited number of previous studies, also coincides with the hypothesis of increased inflammation as a result of increased monocyte-related gene expression during the mood states. There is a need for prospective studies on patients with $\mathrm{BD}$, including genes, gene expressions, monocytes, and MLR values to clarify this subject.

Concerning lipid values, we found that all lipid parameters were higher in remitted patients than healthy controls. It has been reported that lipid metabolism has a role in the course of BD through increased inflammation or other pathways $(19,20)$. However, the current study suggests that the increase in lipid levels, especially during remission, may be a result of regular drug use and weight gain rather than an etiological cause. It is predictable that patients with euthymic state take their medication more regularly and become more sedentary, and this makes them more prone to obesity and hyperlipidemia. Previous studies have also reported increases in lipid levels and weight gain associated with certain psychotropic drugs $(38,39)$. The other striking finding is that patients with mixed state had concurrently higher TG and LDL and lower HDL levels, which are evaluated as coronary risk factors. This may be a result of increased inflammation manifested by an increase in CRP 
levels in mixed episode above mentioned, as well as directly reflecting a metabolic disorder in these patients. Therefore, psychiatrists and other physicians should consider other coronary risk factors when evaluating patients with mixed episode and should keep in mind this aspect in the treatment selection and management.

The use of psychotropic drugs may affect inflammation and blood lipid values in patients with BD. There is evidence that the relative impact of mood stabilizers on the immune system (40). The effect of lithium on the immune system is contradictory because lithium has been shown to have both antiinflammatory and pro-inflammatory effects (41, 42). Compared to lithium, there is much less information about the impact of valproic acid on the immune system. Previous studies have claimed possible anti-inflammatory effects of valproic acid. However, some studies have failed to show a significant anti-inflammatory effect $(43,44)$. The impact of carbamazepine, lamotrigine, and antipsychotics on the immune system also remains unclear due to a lack of clinical studies (45). Studies on the effect of antipsychotic treatment on inflammation indicated mixed findings, showing an increase, a decrease, or unchanged levels of inflammation markers after antipsychotic treatment. This discrepancy may be related to the different effects of antipsychotic agents on the immune system, having both a direct anti-inflammatory activity and an indirect pro-inflammatory activity related to their effect on weight-gain and increased adipose tissue (46).

It cannot be ruled out that our study has some limitations. As this was a cross-sectional study of baseline parameters, the longer-term associations between $\mathrm{BD}$, inflammation, and lipid parameters were not addressed. The retrospective design makes it difficult to establish a cause-and-effect relationship between inflammation parameters and disease. The severity of the illness during episodes and the total number of mood states could not be evaluated, and this may also affect the parameters of inflammation and lipid levels. PLR, NLR, MLR, and MPV have recently been investigated as inexpensive and reproducible markers of systemic inflammation in many diseases. These markers are also suggested as prognostic and reliable determi- nants related to inflammation for many types of systemic disease. Nonetheless, there are mixed and limited data about the sensitivity and specificity of these variables as inflammatory biomarkers in mental and physical disorders. Other limitations include the evaluation of the measurements in different phases of $\mathrm{BD}$, which do not belong to the same patients, using an old diagnostic tool (DSMIV) to diagnose the patients and the small sample size.

\section{CONCLUSION}

In conclusion, our study indicates that there may be an increase in inflammation in all mood episodes, including mixed, depressive, and mania in patients with BD. It suggests that MLR value may be a determinant of increased inflammation in the manic state while CRP values, especially in mixed and depressive episodes. Our findings also claim that patients with BD experience metabolic deterioration, especially during remission and mixed episodes, which may be associated with increased inflammation, and that this should be taken into account in treatment management. However, a larger sample and longitudinal studies are needed to establish a cause-and-effect relationship between inflammation, metabolic parameters, and different episodes of BD.

Correspondence address: Assis. Prof. Okan Ekinci, Department of Psychiatry, Usak University, Usak, Turkey drokanekinci@yahoo.com 


\section{REFERENCES}

1. Hayes JF, Miles J, Walters K, King M, Osborn DP. A systematic review and meta-analysis of premature mortality in bipolar affective disorder. Acta Psychiatr Scand. 2015;131: 417-25.

2. Rosenblat JD, McIntyre RS. Bipolar disorder and Inflammation. Psychiatr Clin N Am. 2016; 39: 125-37.

3. Leboyer M, Soreca I, Scott J, Frye M, Henry C, Tamouza R, Kupfer DJ. Can bipolar disorder be viewed as a multi-system inflammatory disease? J Affect Disord. 2012;141: 1-10.

4. Rosenblat JD, Brietzke E, Mansur RB, Maruschak NA, Lee $\mathrm{Y}$, McIntyre RS. Inflammation as a neurobiological substrate of cognitive impairment in bipolar disorder: evidence, pathophysiology and treatment implications. J Affect Disord. 2015;188:149-59.

5. Modabbernia A, Taslimi S, Brietzke E, Ashrafi M. Cytokine alterations in bipolar disorder: A meta-analysis of 30 studies. Biol Psychiatry 2013; 74: 15-25.

6. Munkholm K, Vinberg M, Vedel Kessing L. Cytokines in bipolar disorder: A systematic review and meta-analysis. J Affect Disord 2013; 144: 16-27.

7. Clyne B, Olshaker JS. The C-reactive protein. J Emerg Med. 1999;17:1019-25.

8. Fernandes BS, Steiner J, Molendijk ML, Dodd S, Nardin P, Gonçalves CA, Jacka F, Köhler CA, Karmakar C, Carvalho AF, Berk M. C-reactive protein concentrations across the mood spectrum in bipolar disorder: a systematic review and metaanalysis. Lancet Psychiatry. 2016;3: 1147-56.

9. DiGangi C. Neutrophil-lymphocyte ratio: predicting cardiovascular and renal complications in patients with diabetes. J Am Assoc Nurse Pract. 2016; 28: 410-4.

10. Zhang H, Gao L, Zhang B, Zhang L, Wang C. Prognostic value of platelet to lymphocyte ratio in non-small cell lung cancer: a systematic review and meta-analysis. Sci. Rep. 2016; 6 (22618): 1-6.

11. Inanli I, Aydin M, Çaliskan AM, Eren I. Neutrophil/lymphocyte ratio, monocyte/lymphocyte ratio, and mean platelet volume as systemic inflammatory markers in different states of bipolar disorder. Nord J Psychiatry. 2019; 73:372-79.

12. Melo MCA, Garcia RF, de Araújo CFC, Abreu RLC, de Bruin PFC, de Bruin VMS. Clinical significance of neutrophillymphocyte and platelet-lymphocyte ratios in bipolar patients: An 18-month prospective study. Psychiatry Res. 2019; 271:8-14.

13. Mayda H, Ahsen A, Bağcioğlu E, Öztürk A, Bahçeci B, Soyuçok E, Başpinar E, Ulu MS. Effect of increased neutrophilto-lymphocyte ratio (NLR) and decreased mean platelet volume (MPV) values on inflammation in acute mania. Noro Psikiyatr Ars. 2016;53: 317-320.

14. Mert DG, Terzi H. Mean platelet volume in bipolar disorder: the search for an ideal biomarker. Neuropsychiatr Dis Treat. 2016;12: 2057-2062.

15. Hotamisligil GS. Inflammation, metaflammation and immunometabolic disorders. Nature. 2017;542(7640):177-185.

16. Wellen KE, Hotamisligil GS. Inflammation, stress, and diabetes. J Clin Invest. 2005;115:1111-1119.
17. Vandanmagsar B, Youm YH, Ravussin A, Galgani JE, Stadler K, Mynatt RL, Ravussin E, Stephens JM, Dixit VD. The NLRP3 inflammasome instigates obesity-induced inflammation and insulin resistance. Nature Med. 2011; 17:179-188.

18. Stienstra R, van Diepen JA, Tack CJ, Zaki MH, van de Veerdonk FL, Perera D, Neale GA, Hooiveld GJ, Hijmans A, Vroegrijk I, van den Berg S, Romijn J, Rensen PC, Joosten LA, Netea MG, Kanneganti TD. Inflammasome is a central player in the induction of obesity and insulin resistance. Proc. Natl Acad. Sci. USA. 2011; 108:15324-15329.

19. Chang HH, Chen PS, Wang TY, Lee SY, Chen SL, Huang SY, Hong JS, Yang YK, Lu RB. Effect of memantine on C-reactive protein and lipid profiles in bipolar disorder. J Affect Disord. 2017; 221:151-7.

20. Chang HH, Chou CH, Chen PS, Gean PW, Huang HC, Lin CY, Yang YK, Lu RB. High prevalence of metabolic disturbances in patients with bipolar disorder in Taiwan. J Affect Disord. 2009; 117: 124-9.

21. American Psychiatric Association. Diagnostic and Statistical Manual of Mental Disorders. 4th ed. Washington, DC: American Psychiatric Association, 2000.

22. Barzilay R, Lobel T, Krivoy A, Shlosberg D, Weizman A, Katz N. Elevated C-reactive protein levels in schizophrenia inpatients is associated with aggressive behavior.Eur Psychiatry. $2016 ; 31: 8-12$.

23. Sağlam Aykut D, Civil Arslan F, Özkorumak Karagüzel E, Aral G, Karakullukçu S. The relationship between neutrophillymphocyte, platelet-lymphocyte ratio and cognitive functions in bipolar disorder. Nord J Psychiatry. 2018;72:119-23.

24. Ivković M, Pantović-Stefanović M, Dunjić-Kostić B, Jurišić V, Lačković M, Totić-Poznanović S, Jovanović AA, Damjanović A. Neutrophil-to-lymphocyte ratio predicting suicide risk in euthymic patients with bipolar disorder: Moderatory effect of family history. Compr Psychiatry. 2016; 66:87-95.

25. Ayhan MG, Cicek IE, Inanli I, Caliskan AM, Ercan Kirci S, Eren I. Neutrophil/lymphocyte and platelet/lymphocyte ratios in all mood states of bipolar disorder. Psychiat Clin Psychopharmacol. 2017;27:278-282.

26. Kalelioglu T, Akkus M, Karamustafalioglu N, Genc A, Genc ES, Cansiz A, Emul M. Neutrophil-lymphocyte and plateletlymphocyte ratios as inflammation markers for bipolar disorder. Psychiatry Res. 2015; 228:925-7.

27. Yildiz M, Batmaz S, Songur E, Sahin S, Demir O. Simple markers for subclinical inflammation in the different phases of bipolar affective disorder. Arch Clin Psychiatry (Sao Paulo). 2016; 43:143-146.

28. Cevher Binici N, Alșen Güney S, İnal Emiroğlu FN. Neutrophil-lymphocyte and platelet-lymphocyte ratios among adolescents with bipolar disorder: A preliminary study. Psychiatry Res. 2018;269:178-82.

29. Cunha AB, Andreazza AC, Gomes FA, Frey BN, da Silveira LE, Gonçalves CA, Kapczinski F. Investigation of serum highsensitive C-reactive protein levels across all mood states in bipolar disorder. Eur Arch Psychiatry Clin Neurosci. 2008; 258: 3004. 
Inflammatory parameters and blood lipid values across the different mood states in patients with bipolar disorder

30. Dickerson F, Stallings C, Origoni A, Boronow J, Yolken R. Elevated serum levels of C-reactive protein are associated with mania symptoms in outpatients with bipolar disorder. Prog Neuropsychopharmacol Biol Psychiatry. 2007; 31: 952-55.

31. Becking K, Boschloo L, Vogelzangs N, Haarman BC, Riemersma-van der Lek R, Penninx BW, Schoevers RA. The association between immune activation and manic symptoms in patients with a depressive disorder. Transl Psychiatry. 2013; 3: e314.

32. Shim IH, Woo YS, Bahk WM. Prevalence rates and clinical implications of bipolar disorder "with mixed features" as defined by DSM-5. J Affect Disord. 2015;173:120-5.

33. Fagiolini A, Coluccia A, Maina G, Forgione RN, Goracci A, Cuomo A, Young AH. Diagnosis, Epidemiology and Management of Mixed States in bipolar disorder. CNS DRUGS. 2015; 29: 725-740.

34. Ozdin S, Sarisoy G, Boke O. A comparison of the neutrophil-lymphocyte ratios in schizophrenia and bipolar disorder patients- a retrospective file review. Nord J Psychiatry. 2017; 71:509-12.

35. Beumer W, Gibney SM, Drexhage RC, Pont-Lezica L, Doorduin J, Klein HC, Steiner J, Connor TJ, Harkin A, Versnel MA, Drexhage HA. The immune theory of psychiatric diseases: a key role for activated microglia and circulating monocytes. J Leukoc Biol. 2012;92: 959-75.

36. Padmos RC, Hillegers MHJ, Knijff EM, Vonk R, Bouvy A, Staal FJ, de Ridder D, Kupka RW, Nolen WA, Drexhage HA. A discriminating messenger RNA signature for bipolar disorder formed by an aberrant expression of inflammatory genes in monocytes. Arch Gen Psychiatry. 2008; 65: 395-407.

37. Padmos RC, Van Baal GC, Vonk R, Wijkhuijs AJ, Kahn RS, Nolen WA, Drexhage HA. Genetic and environmental influences on pro-inflammatory monocytes in bipolar disorder. Arch Gen Psychiatry. 2009; 66: 957-65.

38. Chang HH, Yang YK, Gean PW, Huang HC, Chen PS, Lu RB. The role of valproate in metabolic disturbances in bipolar disorder patients. J Affect Disord 2010; 124: 319-23.

39. Citrome L, Holt RIG, Walker DJ, Hoffmann VP. Weight Gain and Changes in Metabolic Variables following Olanzapine Treatment in Schizophrenia and Bipolar Disorder. Clin Drug Investig. 2011; 31: 455-482.

40. Horrobin DF, Lieb J. A biochemical basis for the actions of lithium on behaviour and on immunity: Relapsing and remitting disorders of inflammation and immunity such as multiple sclerosis or recurrent herpes as manic-depression of the immune system. Med Hypotheses 1981; 7: 891-905.

41. Nassar A, Azab AN. Effects of lithium on inflammation. ACS Chem. Neurosci. 2014; 5: 451-458.

42. Maddu N, Raghavendra PB. Review of lithium effects on immune cells. Immunopharmacol. Immunotoxicol. 2015; 37: 111-125.

43. Lee SY, Chen SL, Chang YH, Chen PS, Huang SY, Tzeng NS, Wang YS, Wang LJ, Lee IH, Wang TY, Yeh TL, Yang YK, Hong JS, Lu RB. The effects of add-on low-dose memantine on cytokine levels in bipolar II depression: A 12-week double-blind, randomized controlled trial. J Clin Psychopharmacol. 2014; 34:
$337-343$

44. Maes M, Bosmans E, Calabrese J, Smith R, Meltzer HY. Interleukin-2 and interleukin-6 in schizophrenia and mania: Effects of neuroleptics and mood stabilizers. J Psychiatr Res. 1995; 29: 141-152.

45. van den Ameele S, van Diermen L, Staels W, Coppens V, Dumont G, Sabbe B, Morrens M. The effect of mood-stabilizing drugs on cytokine levels in bipolar disorder: A systematic review. J. Affect. Disord. 2016; 203: 364-373.

46. Zajkowska Z, Mondelli V. First-episode psychosis: an inflammatory state? Neuroimmunomodulation. 2014;21:102-8. 